\title{
Critical analysis of valuation and strategical orientation of merger and acquisition deals in the pharmaceutical industry
}

\author{
Raphaela Marie Louisa Dierks, Olivier Bruyère and Jean-Yves Reginster \\ Faculty of Medicine, Department of Public Health, Epidemiology and Health Economics, CHU Sart-Tilman, Liège, Belgium
}

\begin{abstract}
Introduction: The pharmaceutical industry is undergoing major shifts due to changing macro and micro factors. As the industry is highly capital intensive and patents are expiring, the outlook is on generating inorganic growth, mainly through M\&A. Using the income valuation approach, one analyses two completed deals in 2016 above 1 bn USD. Thereafter one outlines the main motives behind M\&A deals and concluded by discussing whether M\&A harms medical innovations.

Areas covered: The paper is based on empirical study questioning existing literature in order to critically analyse valuation and the strategical orientation of pharmaceutical companies

Expert commentary: Pharmaceutical companies understand the changing market conditions and favour their expertise. The restructuring of the industry moves to small niche companies (l.e. Biopharma or biotech companies) researching key innovations and big companies purchasing them to develop them, create clinical trials and distribute them as this is a costly manner

Conclusion: One can expect more M\&A deals during the next years focusing on value rather than volume. Pharmaceutical players resilient to the market changes may survive if they change their business model from a traditional vertical one to outsourcing and diversification including external players.
\end{abstract}

ARTICLE HISTORY

Received 21 October 2017

Accepted 11 December 2017

\section{KEYWORDS}

Pharmaceutical industry; merger and acquisitions (M\&A); valuation; inorganic growth; medical innovation; non-core assets; drug pipeline; tax inversion

\section{Introduction}

The pharmaceutical industry is very capital intensive with many barriers to entry such as high cost of research and development (R\&D) [pharmaceutical expenditure in $R \& D$ in USA, Japan, and Europe is increasing massively each year, 1995: 29.8mn EUR, 2005: 63.14mn EUR (+112\% from 1995 to 2005), 2015: $95.2 \mathrm{mn}$ EUR (+51\% from 2005 to 2015 and $+219 \%$ from 1995 to 2015 [1])], regulatory policies, or pricing pressures [2]. To remain profitable, companies need to build up and enhance their economies of scale. A practice well known in the industry is diversification by entering generic drug research and manufacturing. This requires less capital but comes also with lower profit margins. Patents are crucial for pharmaceutical companies. The impact of expiring patents on revenues is expected to reach 259bn USD between 2014 and 2020, with 70bn USD at risk in 2016/17. This involves all major players, i.e. Pfizer's Alimta against cancer expired 2016, AstraZeneca's Crestor for lowering LDL cholesterol expired 2016, or Merck's Cubicin against bacterial infections also expired in 2016, to name only a few [3]. Future estimates are even more frightening with provision of sales at risk during 2017 and 2022 of USD 194bn due to expiring patents. This is mainly linked to further growing external and internal factors hitting pharmaceutical companies. Next to generics, pharmaceutical companies are also intensively looking at researching and developing medicines for new drugs with rare diseases, where they can demand reimbursed prices (i.e. cancer, orphan diseases) or ask funding from governments for drugs such as antibiotics to develop the market and enable sustainable investments necessary for the development of highly scientifically challenges discoveries or to collaborate with governments to help lower income countries to afford drugs (i.e. Novartis trying to make cardiovascular diseases, diabetes, respiratory diseases, and breast cancer affordable in Kenya [4]). Both, strategy for generics diversification as well as collaborations developing are practices well known in the pharmaceutical industry.

This shows that major market players are seeking for alternative strategies to remain competitive and respond to the increasing worldwide drug prescriptions that are expected to grow at $+6.5 \%$ compound annual growth rate until 2022 to reach 1.06trn USD [5]. The 1.06trn USD target is split between 112bn USD generic sales (10.6\%), 209bn USD orphan drug sales (19.7\%), and $739 \mathrm{bn}$ USD other sales of prescriptions $(69.7 \%)$ [5]. To respond to the fast-moving market, the new demand from epidemiologic transition and to create new innovative drugs, pharmaceutical companies are more strategically looking for the generation of inorganic growth as organic growth is moving at slow pace due to the hitting external macro requirements. Inorganic growth is the growth rate by growing profits through external deals such as collaborations, venture capitals, or Mergers and Acquisitions (M\&A). As pharmaceutical companies are strongly looking at $M \& A$ as it allows growing the company earnings rapidly while creating 
meaningful synergies, this paper focuses solely on this growth strategy.

The years 2014 and 2015 were strong years of M\&A activity, both in terms of volume and value. While 2016 saw some signs of fatigue in terms of value with $325.8 \mathrm{bn}$ USD (vs. 451.5bn in 2014 and 578bn USD in 2015) [6], one can analyze from Figure 1 that the 2016 figure is in line with the value in prior years before the storm of 2014/15. The decrease in M\&A deals in 2016 was mainly driven by three factors: (1) the Obama regime blocked transactions motivated by tax inversions, (2) only few remaining targets after the big merger mania in 2014/15, and (3) falling price/earnings ( $P / E$ ) ratios at lower end of historical levels with a stronger US dollar and a slow adoption growth rates for some products [7].

Analysts are pretty optimistic for the upcoming years as pharmaceutical companies feel the need to restructure their portfolios with M\&A representing the most efficient instrument.

\section{Methodology}

This paper critically analyzes and investigates both valuation and strategical orientation of M\&A in the pharmaceutical industry. For this research, one has gathered data through literature reviews mainly researching for the big four accounting firms (Deloitte, PwC, EY, KPMG), market observations and analyses from financial specialists (consultants, investment bankers), top newspapers (Reuters, CNBC), and the employment of the financial tool Bloomberg for market news, data, analysis to enable one to make calculations. Literature was gathered by using the main keywords: $M \& A$, development, pharmaceutical industry, restructuring, business model, valuation of companies, tender offers, share prices, drugs, and portfolio.

This empirical research is introduced with a brief historical development of $M \& A$ in the pharmaceutical industry to understand the evolution of M\&A transactions in terms of value and volume over a 10-year horizon (2006-2016) (Figure 1) and shows all M\&A deals above 1bn USD completed in 2016 in the pharmaceutical industry (Table 1).

Thereafter, one will outline the principles of valuation including the most important calculation methods as it is a complex discipline and needs to follow some main rules of thumb to understand how much a company is worth. Explaining the structure of a tender offer concludes the theory, as the paper is focusing on two hostile takeovers.

After the fundamental theory and literature review has been reviewed and explained, the researchers are analyzing two examples of completed M\&A deals above 1bn USD in 2016. Pfizer acquiring Medivation and Mylan acquiring Meda to present the sequence within a tender offer and subsequently analyze the evolution of share prices from the acquirer and the target through a scientific financial approach using financial data providers. These two examples were chosen as the median of M\&A volumes above $1 \mathrm{bn}$ USD in 2016 is $8.32 \mathrm{bn}$ USD, and these two examples are slightly above this median and are in the top three completed deals. This allows going beyond simple reporting observations and getting raw complex data able to calculate and analyze, to show short and long-term impacts of M\&A transactions. This real-world environment allows to prove relevancy of valuation multiples.

In a second step, the research design focuses on the main motives for M\&A transactions and whether they are resilient to the core business models of the acquirer. This part is based on a fundamental literature review, manly using economical and financial concepts, such as selling-off or Markowitz portfolio theory, as well as a review of the US tax environment, to create evidence-based statements relating to $M \& A$ in the pharmaceutical industry.

Table 1. All M\&A deals above 1bn USD in 2016 (total 74.9bn USD) [8].

\begin{tabular}{lll}
\hline Acquirer & \multicolumn{1}{c}{ Target } & $\begin{array}{l}\text { Value } \\
\text { (USD) }\end{array}$ \\
\hline $\begin{array}{l}\text { Shire } \\
\text { Pfizer }\end{array}$ & Baxalta & $35 \mathrm{bn}$ \\
Mylan & Medivation & $14 \mathrm{bn}$ \\
AbbVie & Meda & $9.9 \mathrm{bn}$ \\
Pfizer & StemCentRx & $5.8 \mathrm{bn}$ \\
Pfizer & Anacor Pharmaceuticals & $4.5 \mathrm{bn}$ \\
& AstraZeneca (small-molecule & $1.6 \mathrm{bn}$ \\
Horizon Pharma & antibiotics business) & \\
Galencia & Raptor Pharmaceutical & $1.5 \mathrm{bn}$ \\
Jazz Pharmaceuticals & Relypsa & $1.4 \mathrm{bn}$ \\
\hline
\end{tabular}

This means that there were various small deals next to the nine big deals in 2016 for $250.9 \mathrm{bn}$ USD (the total M\&A value in 2016 was of $325.8 \mathrm{bn}$ USD).

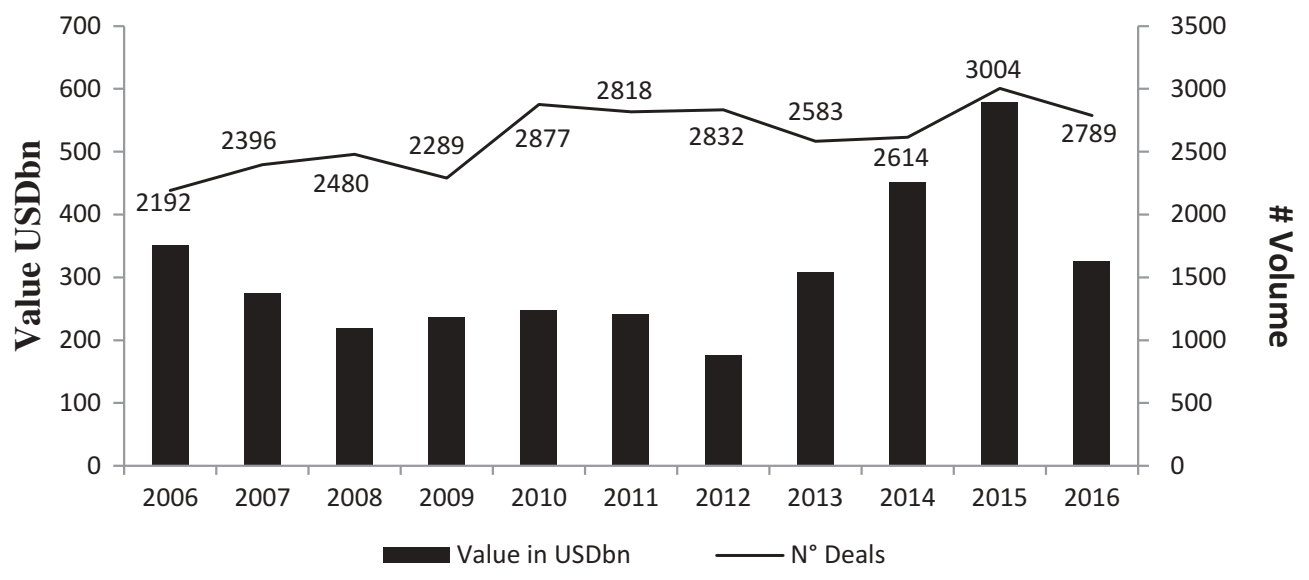

Figure 1. Evolution of $M \& A$ Deals in the Pharmaceutical Industry over a 10-year time horizon.

Source: KPMG Predictor [6] 
In a third step, the empirical research undergoes a brief discussion whether M\&A harms innovations in the pharmaceutical industry and then concludes with a recommendation plan for pharmaceutical companies.

\section{Valuation of a pharmaceutical company}

\subsection{What is valuation?}

Valuation is the procedure of defining the current worth of an asset. Analysts are using different factors, techniques, and calculation methods to define the right value. Main factors they are looking at are the management of the company, the capital structure (financing of the company operations and potential growth opportunities, meaning equity or debt), the future earnings, and the market value (i.e. what the company is worth in the market, or what the underlying assets are worth in the market) [9]. This means that valuation depends on not only various internal factors, such as the drug pipeline, patent rights, M\&A activities, the overall company health, but also the market potentials and some external macro trends. Also, the market value is defined by what an acquirer is willing to pay to its target. When companies are traded on a stock exchange, the target is defined by the market value of the stock.

\subsection{How to value a company?}

In order to value a company, analysts are using different approaches. The three main approaches to consider are the asset, the market, and the income approach. One explains all three approaches below, focusing on the income approach as it allows to define the overall economic value of a business.

\subsubsection{Asset approach}

One valuation method is the asset accumulation. It measures the difference between the current value of all underlying assets in one business and the current value of all the company's liabilities (loans, accounts payable, deferred revenues, and accrued expenses). It allows showing the fair market value, so the fair value that a buyer would offer to its target. Interesting about the asset accumulation is that off-balance sheet variables are included in the valuation, such as IP, exclusive contracts with distributors, any strategic contracts, or partnership agreements. This approach shows the valuation of the underlying assets in one company.

\subsubsection{Market approach}

The market approach is used to calculate the appraisal value of an asset, meaning the valuation of a business or real estate by an authorized person (i.e. auditor) based on the selling price of a similar asset. It shows the value of a company's ownership interest, security, and tangible assets. All assets are valued against recent sales of similar assets, by making adjustments for size, quantity, and quality.

\subsubsection{Income approach}

This valuation looks at the economic value of a business by analyzing future returns the acquirer can expect from the target. To do so, one calculates various multiples that will be discussed in a next step:

The impact of earnings on valuations and the overall company valuation are key considerations:

(1) Earnings on valuations: Earnings per share (EPS): When analysts are using the EPS formula, they divide the earnings available to the existing shareholders by the number of outstanding stock shares. EPS is calculated to understand how profitable a company is. The more earnings a firm generates per share, the more attractive and valuable every share is to the investors. In 2016, one has downgrading earning momentums, especially with US large caps as concerns on US drugs pricing are present due to major abuses (i.e. EpiPen, Section 2.2).

(2) Earnings on valuations: P/E ratio: Also, analysts are using the $P / E$ ratio to value a stock, calculated by dividing the market price per share by the EPS. This ratio expresses how expensive a price of a stock is compared to the earnings created per share. Also, this translates into how much an investor is willing to pay for each dollar of earnings. Once an analyst has calculated the P/E ratio, and the stock would show for instance 30 times earnings, the analyst would compare it to the benchmark ratio and/or competitors from the same industry ratio to see the attractiveness of the firm. For instance, Novartis shows very strong P/E at $28.8 \times$ compared to $20.76 \times$ of the free-float weighted equity index $\mathrm{MSCl}$ World Index, including mid and large-cap performance across 23 developed market countries (30 December 2016). However, overall pharmaceutical stock valuation is also at the lower end of historical levels trading with US large cap trading average at $15 \times$ and European large cap average at $14 \times$ [10].

(3) Overall company valuation: However, some analysts prefer the Enterprise Value to Earnings Before Interest, Depreciation, Taxes, and Amortization (EV/EBITDA) ratio as opposite to the two abovementioned earnings on valuations multiples (EPS, P/E). This ratio is expressed for very capital intensive companies and the valuation preference is due to it shows the overall company value and is capital structure neutral. Also, it is more precise than the P/E ratio, as it includes the operational earnings (EBITDA vs. the net profit) and the overall company value (including debt, cash, and minority interests). The EV/EBITDA shows whether a company is over- or undervalued. For instance, in 2015, Europe showed to be a seller market, with an average valuation of $17 \times$ EBITDA [11].

One believes that the calculation of all three multiples is the best to use when valuing bigger pharmaceutical companies due to their relatively stable earnings and capital intensive businesses.

Thereunto, analysts are putting a value to the asset by calculating the cash inflow and outflows created by this asset. One 
discounts the cash flows (CFs) in a value by using the discount rate. The discount rate expresses an assumption of interest rates or the minimal return rate what an investor would expect. For instance, when a company is purchasing a new drug, the company will analyze on one side the cash outflows necessary for this purchase and on the other side, it will calculate the cash inflows generated by this new drug. The CFs are discounted to the present value. If this present value also called net present value shows a positive number, the company should consider the purchase as the investment is a good buy. Therefore, the CF shows the movement of cash inflow (revenues) and outflows (expenditures) created from an asset or firm. This means that the CF determines the liquidity of a firm.

On the other side, the free cash flow (FCF) is calculated as difference between the operating $C F$ and the actual capital expenditure (equipment, buildings, etc.). This FCF shows the actual cash available to the company and expresses therefore the financial performance of a company. If cash is available, it creates new opportunities that augment the shareholder value, as for instance dividends would be higher if more cash is available, or new assets could be founded that could increase the share price. It shows how much cash can be apportioned among all the shareholders. This means that the FCF determines the overall financial health of a company. A positive FCF expresses that the company has enough cash to run its business efficiently, while a negative FCF shows that the company is not able to create enough cash or has overinvested some money that might create higher returns in future periods.

Table 2 shows a summary of CF and FCF as all investment and financing choices are conditioned by these two aspects.

Table 3 shows a summary of what the three approaches express for a company.

\subsection{Valuation of deals above USD 1 bn in 2016}

The pharmaceutical industry is an industry spending a lot of capital on their R\&D activity. It takes an average of 12 years that a new drug is researched and brought to the patient. In addition, only 5 out of 5000 are actually passing the preclinical testing to the human testing. Finally, only one out of five is approved for human use [13]. This shows that pharmaceutical companies need to be very stable to create profitability and organic growth. As highlighted, this is very difficult nowadays and therefore companies are looking for external growth. In order to achieve external growth, pharmaceutical companies need to target the right company, reason why the financial metrics described here above are calculated and analyzed to show the potential return on investment a company and its investors would achieve.

Table 2. Resume of CF and FCF [12].

\begin{tabular}{|c|c|c|}
\hline & Cash flow & Free cash flow \\
\hline Definition & $\begin{array}{l}\text { Cash inflows and cash } \\
\text { outflows }\end{array}$ & $\begin{array}{l}\text { Available cash to a company (that can be } \\
\text { paid out to shareholders or invested) }\end{array}$ \\
\hline Reason & Solvency of the firm & Performance of the firm \\
\hline Calculation & $\begin{array}{l}\text { Sum of all revenues - } \\
\text { sum of all } \\
\text { expenditures }\end{array}$ & $\begin{array}{l}\text { EBITDA - working capital } \\
\text { changes + capital expenditure }\end{array}$ \\
\hline Result & $\begin{array}{l}\text { Liquidity of the } \\
\text { company }\end{array}$ & $\begin{array}{l}\text { Overall financial health of the } \\
\text { company }\end{array}$ \\
\hline
\end{tabular}

Table 3. Summary of the tree main value approaches.

\begin{tabular}{lcc}
\hline Asset approach & Marketing approach & \multicolumn{1}{c}{ Income approach } \\
\hline $\begin{array}{cc}\text { Fair market value } \\
\text { of what a }\end{array}$ & $\begin{array}{c}\text { How much the } \\
\text { market is paying }\end{array}$ & $\begin{array}{c}\text { Valuation of a company on the } \\
\text { ability of generating income } \\
\text { (economic benefit) }\end{array}$ \\
\hline
\end{tabular}

As the top pharmaceutical companies are publicly traded, the financial data are available to the market and one can compare the companies and their assets with competitors and industry multiples. Table 4 is comparing the key multiples of the acquirer and target companies involved in the 2016 deals above USD $1 \mathrm{bn}$.

Comparing the key financial multiples of the pharmaceutical companies involved in 2016 deals above 1bn USD in Table 4 to the benchmark MSCI World Index, one can analyze the following:

- The average EV/EBITDA is at $14.59 \times$ versus $12.05 \times$ of the benchmark, with all acquirer companies above the benchmark.

- The average $P / E$ ratio is at $17.37 \times$ versus $21.05 \times$ of the benchmark, with all acquirer companies below the benchmark.

- The average P/CF ratio is at $12.66 \times$ versus $11.43 \times$ of the benchmark, with Mylan and Horizon Pharma below average.

Concluding, the acquirer has a target company to take over, and the dedicated Investment Bankers calculate all multiples and factors described here above. This allows the acquirer to justify the valuation of the target and vice-versa including the takeover price estimation, with the premium included. The intention of the acquirer is to minimize the amount that needs to be paid to the target shareholders, while the target's aim is to maximize the amount that will be paid to its shareholders. This means that in an ideal world, the acquirer does not want to pay more than the premerger value of the target plus the value of the synergies, but the target shareholders want to maximize their gains and would not accept anything below the premerger market value. The formula to apply to calculate the target shareholder's gain would be as follows: Premium $=P_{\mathrm{T}}-V_{\mathrm{T}}$, where $P_{\mathrm{T}}$ equals the price to pay for the target company and $V_{\mathrm{T}}$ expressing the premerger value of the target company. This means that the acquirer gain equals the synergies minus the premium or with the formula: Acquirer gain $=S-\left(P_{\mathrm{T}}-V_{\mathrm{T}}\right)$, with $S$ presenting the synergies created by the combination of the two businesses. Summing up, the combined formula to calculate would be as follows:

Post-merger value of the combined companies $=V_{\mathrm{A}}+V_{\mathrm{T}}+S-C$, where $V_{\mathrm{A}}$ is the premerger value of the acquirer and $C$ is the actual cash paid to the target shareholders.

In a further step, one will explain the valuation of two big pharmaceutical companies that were involved in M\&A deals above USD 1 bn in 2016, Pfizer acquiring Medivation and Mylan merging with Meda. Both companies have used tender offers to complete the transactions. Tender offers are widely used in the M\&A business, as hostile takeover, where the offer is directly made to the target's shareholders, not to the target 


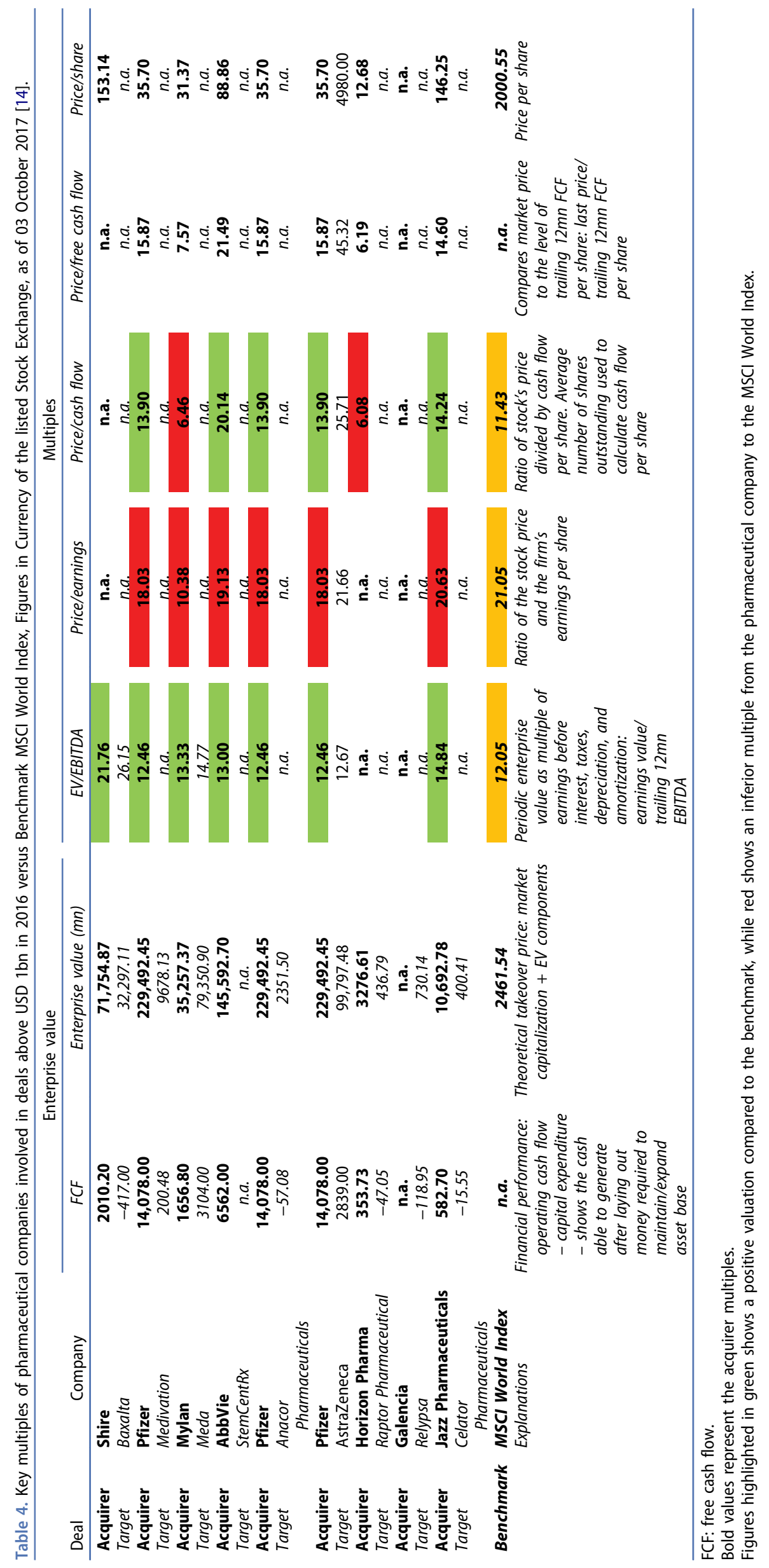


board. Figure 2 illustrates the structure of a tender offer which has two major steps.

In a two-step merger, the target will become a wholly owned subsidiary of the acquirer. The acquirer starts a tender for all the target's shares and can be completed in a few days. In case that the transaction is fully cashed, the merger can be completed in 1-2 months in case no regulatory issues occur. Once the target shareholders have agreed to the tender, the acquirer purchases all tendered shares and becomes a majority shareholder of the target to follow up with a merger. The target continues to exist, but the acquirer gains full control.

\subsubsection{The tender offer of Pfizer acquiring Medivation for USD $14 b n$}

Pfizer, one of the world's largest pharmaceutical companies based in the Unites States, offers drugs for immunology, oncology, cardiology, and neurology. Its size allows them to have competitive advantage in developing new drugs, holding a portfolio of patent-protected medicine with strong pricing power, allowing the company to generate low volatility CFs and return on invested capital in excess of its cost of capital. However, as patents are expiring, the company loses exclusivity on drugs, for instance on their drug against cholesterol Lipitor or the blockbusters Celebrex or Zyvox. Therefore, the company aims to create fast external growth rather than slow organic growth through its M\&A activity. After Pfizer's default in 2016 buying Allergan to save almost $125 \mathrm{mn}$ USD of taxes, they made a tender offer to Medivation, the cancer drug developer, in order to keep its leading position in oncology [15].

Pfizer made a tender offer for all outstanding shares of Medivation with transaction value of USD 81.50 per share in cash, for a total enterprise value of USD $14 \mathrm{bn}$. In total $115,574,041$ shares were tendered, translated into a $69.1 \%$ acceptance rate of existing shareholders, excluding any interest. This share price represents a $21 \%$ premium compared to Medivation's share price on Friday, 18 August 2016 at USD 67.19, and above the record close of Medivation in March 2015 of 67.78 USD per share. The transaction was paid by Pfizer with existing cash. All shares that were not tendered were acquired in a second step in 2016. Medivation was in focus as target of many big pharma companies, due to its unique position in the biopharmaceutical sector focusing on innovative therapies treating serious diseases where today's treatments are very limited such as in prostate cancer [16]. Sanofi also tried to target Medivation, however with a very aggressive takeover offer of USD 9.3bn, that was rejected.

Pfizer's Board of Directors and Medivation have both agreed to the merger, being immediately accretive to Pfizer's adjusted diluted EPS upon closing. The diluted EPS is a profitability measure taking into account all convertible securities which express the quality of EPS of a company, with the assumption that all convertible securities (including all outstanding convertible preferred shares, convertible debt, equity options, employee-based options, warrants) are exercised. Pfizer's adjusted EPS was of USD 0.05 accretive in the first full year after deal close with additional accretion potential and growth anticipation. Medivation's shares have risen by $66 \%$ from January to August 2016 [17]. Pfizer's shares have dropped 1\% on Monday, 22 August 2016 when the acquirer announced to buy Medivation. This significant short-term change in share price is normality with $M \& A$ transactions. The share prices of the acquirer normally drop as the acquirer needs to pay more than the target company is currently worth to create an attractive offer. Thereunto uncertainties around M\&A deals drop the acquirer share price, such as additional debt or expenses that will be taken over by the acquirer to make the deal go through or accounting issues such as restructuring charges. However, one can analyze that if a transaction goes efficiently, the drop is of short-term nature and the acquisition

Step 1:

\begin{tabular}{|l|l|l|}
\hline Acquirer (A) \\
1. A, T and MS sign \\
merger agreement \\
to buy TS
\end{tabular}

Step 2:

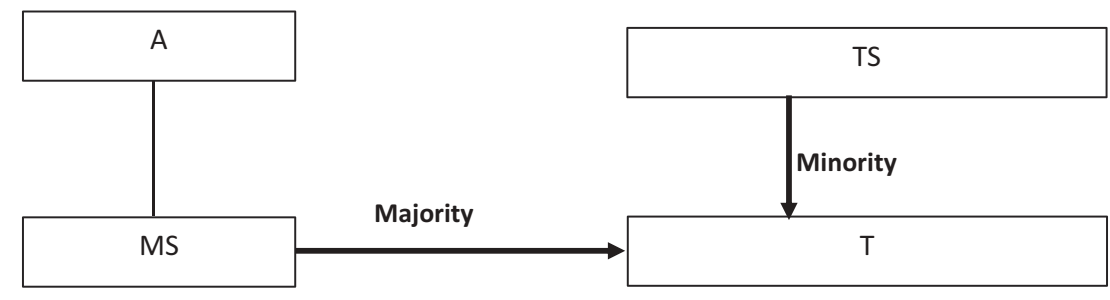

Figure 2. Two-Step Tender Offer Structure. 
is normally a good deal for the acquirer in the long-term run if the right company has been chosen and valued adequately, and previously financial economic considerations have been thought of.

Figure 3 analyzes in more detail the share price movements of Pfizer and Medivation since beginning of 2016, where Medivation become very attractive to big pharmaceutical companies (Pfizer, Sanofi etc.) until Pfizer's takeover.

In February 2016, the US FDA approved some additional new drug applications for Medivations core drug Xtandi that allows including TERRAIN and STRIVE trials. The TERRAIN trial compares enzalutamide versus biculutamide in men who do not have symptoms with metastatic diseases progressing on hormone therapy. The STRIVE trials compare castration-resistant non-metastatic or metastatic diseases [18]. Thereunto, Medivation made a presentation at the American Association for Cancer Research on 17 April 2016 announcing phase I of Talazoparib. Both events were positively received, with consequently jumping share prices. Adding to these two research events, the biopharmaceutical company received on 15th April a nonbinding offer from Sanofi to acquire all outstanding shares at a price of USD 52.50 per share, representing an undervaluation of the company. However, speculations on a takeover started already beginning of the year that caused a surge in Medivation's share price.

In Q3 2016, Pfizer made the offer to Medivation at a fair value of USD 81.50 per share reprinting a premium of $21 \%$ compared to the share price of 67.19 on 18th August. On 22nd August when the deal was officially announced, the share price climbed to USD 80.42 , closing at USD 81.44 on the deal closing day 27th September.

Pfizer shows that it is a well-perceived pharmaceutical company with less volatile share prices. On 18th August, its share price was of USD 35.19 per share falling slightly of 99bps to USD 34.84 on 22nd August. Until deal closed, it lost additional $2.90 \%$, totaling a short-term loss of $3.86 \%$ in the acquisition period of Medivation. Since the deal closed until 18 August 2017, Pfizer's share prices increased for +2.51 , with return figures for the year of 2016 of $+4.46 \%$. It shows that in a long-term run, the acquisition did not hit the stock price and translated into a good acquisition and positive share price results.

The aim of this transaction for Pfizer is to grow revenues, drive earnings growth, and become a leader in oncology. Pfizer's group president $A$. Bourla analyzes the transaction:

Given the breadth of Pfizer's existing oncology portfolio and emerging immuno-oncology pipeline, Medivation's assets will potentially benefit from many novel and productive combinations. Together, we are well positioned to becoming a leading oncology company, speeding cures and making accessible breakthrough medicines to patients - our number one priority. [19]

The target became a wholly owned subsidiary of the acquirer. The two companies started their joint operations on 28 September 2016 to increase their market power and commercial scale in oncology focusing on new cancer treatment innovations. This tender offer shows how capital can be deployed in an effective way to generate attractive returns and create additional shareholder value. Pfizer acquired the key innovative prostate cancer drug Xtdandi, blocking various steps in the androgen receptor pathway in the cell affected by the tumor. Xtdandi has achieved USD 2.2bn net sales in 1 year. Moreover, the late-stage oncology pipeline of Medivation is very attractive and adds value to Pfizer's portfolio, such as Talazoparib which is in Phase III study treating breast cancer or Pidilizumab developed to diffuse B-cell lymphoma.

This acquisition allows Pfizer to strengthen its position in the field of oncology, important as cancer remains the second leading cause of death worldwide [20].

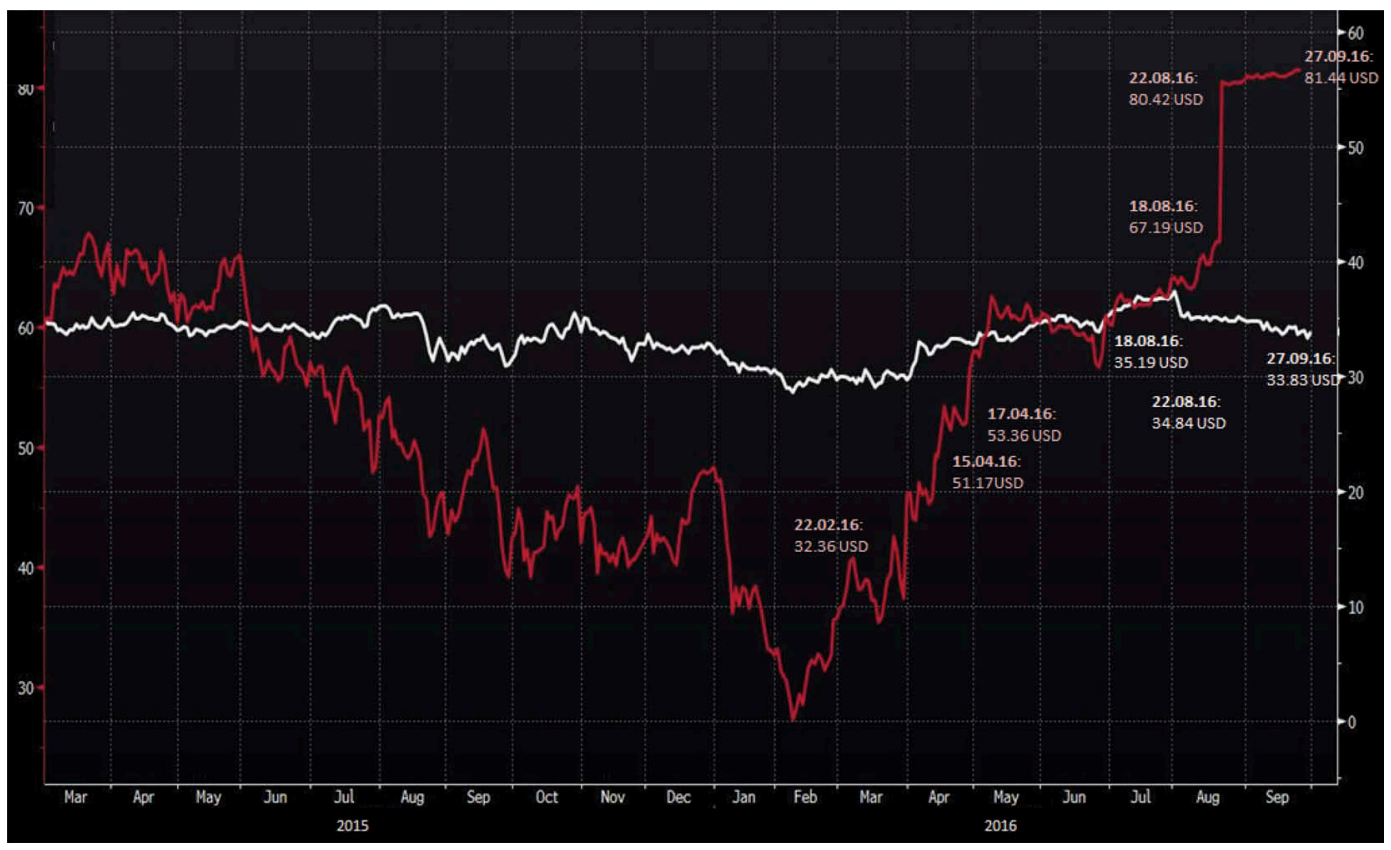

Figure 3. Evolution of Medivation's share price versus Pfizer's share price. The white line shows Pfizer's share price evolution and the red line shows Medivation's share price movement [10]. Full color available online. 


\subsubsection{Second example of Mylan acquiring Meda in a tender offer for USD $9.9 \mathrm{bn}$}

Mylan, the global pharmaceutical company from the United States, made a tender offer to Meda, a Swedish drug maker on 16 February 2016 for all their shares. The entire offer consists of cash and Mylan ordinary shares with a value of SEK 165 (USD 20.22) per Meda share. The total value for the transaction is of USD 9.9bn (USD 7.2bn without debt) showing a multiple of $8.9 \times$ EBITDA including synergies (12.9x EBITDA without synergies). Prior to the announcement, Meda's valuation was at 3.7bn USD [21]. Meda's board of directors recommended to its shareholder to accept this offer due to its significant premium delivering immediate shareholder value. Also, Meda's two largest stakeholders holding approximately $30 \%$ of outstanding shares accepted the offer, in contrast to its rejection in 2014 where Mylan wanted to acquire Meda for USD 6.7bn [22].

After the announcement, Mylan's share price dropped by $18 \%$ due to several reasons. First, the earnings in Q4 2016 were negatively impacted by higher nonoperating expenses (i.e. unrealized mark-to-market losses on Mylan's Swedish currency contracts) that distressed the investors. Second, Mylan's investors disliked the noise to acquire Meda, as they did already a first offer in 2014 that was rejected. Third, Mylan paid a very high premium of $92 \%$ over Meda's market value, which defines one of the highest premiums ever made in the pharmaceutical industry [23]. Moreover, this deal was made after the merger-mania 2015 in a year where companies were overvalued. Lastly, it has to be said that Mylan not only made different M\&A attempts such as the hostile failed attempt to acquire the drug maker Perrigo but also made some deals that made derogatory headlines such as the deal with Abbott INC's specialty and generic business, based in the Netherlands, only for tax inversions.
With the acquisition of Meda, Mylan can benefit from a similar portfolio to Perrigo, with over-the-counter (OTC) drugs. However, one can mention that Mylan's success is based on M\&A deals, as it was a much smaller company 10 years ago. The deal of Mylan acquiring Meda was completed on 5 August 2016 strengthening its global diversified portfolio and gain market access in China, South Asia, Russia, and the Middle East. This allows Mylan to become a leading global player in the field of allergies and respiratory and add significant value in dermatology and pain treatments.

This deal should be immediately accretive adding USD $0.35-0.40$ to the diluted EPS. Moreover, operational synergies are expected to be of USD $350 \mathrm{mn}$ annually.

Figure 4 shows the evolution of Meda's versus Mylan's share price since announcement of the deal. On 9 February 2016, Meda's share price was at SEK 83.05 (USD 10.22), climbing in 2 days to SEK 143.90 (USD 17.71) presenting a 73.27\% increase. In the week when the offer was finalized, the price increased further $11.67 \%$ to SEK 160.70 (USD 19.78) presenting Meda's high during its lifetime, seeing SEK 154 (USD 18.95) on the day of the deal closing (05 August 2016) and closing off on 23rd August at SEK 156 (19.20 USD). This means that since announcement to close Meda's share price rose in total by $87.84 \%$

On the other side, the share prices of Mylan dropped from 9th February to 11 th February by $18.37 \%$ from USD 50.74 to 41.42 USD. Until the last week of the deal close, Mylan's share increased back $17 \%$ to USD 48.46 on deal closing day. This shows that the acquisition of Meda was relatively neutral for Mylan with only short-term lows in the share price.

These two examples of Pfizer acquiring Medivation and Mylan acquiring Meda show that on a short-term basis the valuation of the acquirer (incl. share prices) decline due to various reasons such as high volatility in share prices, the

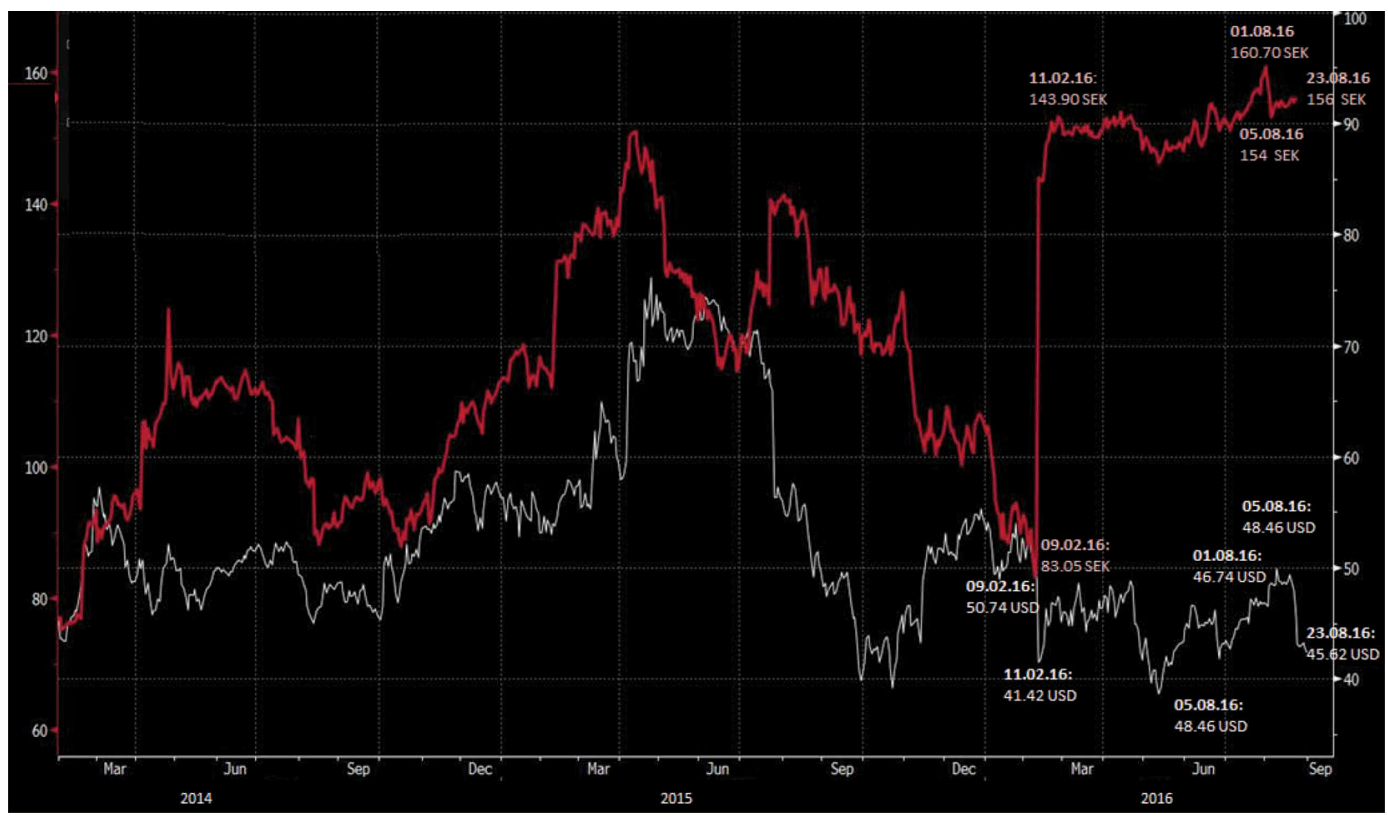

Figure 4. Evolution of Meda's versus Mylan's share price. The white line shows Mylan's share price evolution and the red line shows Meda's share price movement [24]. Full color available online. 
acquirer taking on too much debt, lack of synergies or too high premiums paid to the target, but in the absence of unknown economic conditions recover rapidly shifting towards a higher valuation of the acquirer and target together, due to the share price arbitrage. Share price arbitrage means taking on a long position in shares of the target and a simultaneous short position in the acquirer shares, once the takeover is public. Also, long-term performance increases in the absence of economic uncertainties and greater dividends might be paid to shareholders.

\section{Are the transactions strategically oriented, resilient to the core business model?}

With a second research question, this paper aims to analyze first the main motives behind M\&A deals, an ex-ante concept, and second whether $M \& A$ transactions in the pharmaceutical industry are strategically oriented, resilient to the core business model, an ex-post concept. As markets remain volatile, competition increases and internal R\&D is often cost and time efficient, big players are looking for external alternatives, with $M \& A$ as valuable strategy, to answer the increasing demand (i.e. epidemiologic transition) and comply with new regulations and pricing pressures.

Analyzing the M\&A deals achieved between 2006 and 2016, one has identified three main motives for $M \& A$ transactions:

(1) Restructuring of the entire business operations or part of it to gain more purchasing capacities and selling of noncore assets to improve profitability and add value on niche parts of the business

(2) Enhancing the portfolio through the acquisition of new drugs to remain a competitive market player and grow inorganically

(3) Shifting of the tax domicile through tax inversion deals

In a next step, one will outline the three motives described here above through real examples including the resilience to the core business strategy.

\subsection{Restructuring and selling of noncore assets}

Companies are using M\&A activities to sell noncore assets of the company, in order to focus on key assets. For instance, the British pharmaceutical company AstraZeneca has decided to sell off different noncore assets within the company. To name some examples of AstraZeneca to reduce their portfolio diversity and sell of noncore assets, are for instance the Alzheimer drug that was sold to Eli Lily for more than USD $500 \mathrm{mn}$, or another USD 200mn deal with Daiichi Sankyo, or a USD 300mn deal with Recordati for its aging beta-blocker heart drug Seloken [25]. The idea behind selling-off noncore parts of the business is to spin-off costly areas that don't drive revenues upward, and to focus on key resources and target new assets that are more in line with the key business strategy and can deliver growth. This strategy allows funding new assets by existing funds, rather than growing one's debt. Also, spinoffs are implemented to help stabilizing earnings when patents are expiring. Moreover, it allows saving costs on noncore assets through the reduction of cost or production, financial, or fixed costs [26].

Another supporter of this rationalization concept is the Swiss pharmaceutical company Novartis, selling off noncore assets to add cash and focus sales on key assets. Novartis has for instance sold some different products to the Indian pharmaceutical company Sun in Japan for USD 293mn, as they had own issues entering the Japanese market [27].

Noncore assets are neither essential nor used by the business to generate core revenues. However, they help to deploy cash for future assets that might have massive growth characters. For instance, AstraZeneca sold off their noncore assets to invest into the development of new drugs that could be blockbusters in the area of oncology and other severe diseases. GlaxoSmithKline also used this practice to offload different noncore assets. Selling-off noncore business parts is often used as short-term or medium-term strategy to reduce the level of debt or have enough capacities to manoeuver for new long-term acquisitions [28].

This shows that selling-off noncore parts of a business is a strategic decision of pharmaceutical companies, resilient to the core business model to focus on the growth generating assets and generate CFs for future acquisitions of core assets.

\subsection{Grow bigger by building a sustainable portfolio and valuation}

Next to selling-off noncore assets, M\&A deals are favored in the pharmaceutical sector to enhance one's portfolio, diversify globally, and keep their revenues growing in the expected investors pace. As presented, it gets more difficult for pharmaceutical companies to breakthrough with new innovative drugs, as costs are increasing, regulations are tightened, and demand more sophisticated. Therefore, it is often cheaper to acquire an existing drug or even an entire company with an existing asset portfolio rather than developing in house $a b$ initio. This motivation is enhanced through low interest rates that translate into cheap capital, easy to fund the acquisitions with debt. Diversification in different areas related to the modern portfolio theory [28], which explains that the market value of a company can increase when one invests into different assets, especially if they are less correlated, however differing from conglomerate mergers, mergers that are transactions between firms of totally unrelated business activities [29]. As outlined in the modern portfolio theory, mergers area also a way to diversify risk and maximize expected returns [30].

Such an event was seen in the previously analyzed Mylan acquiring Meda case. Mylan's reasons behind the Meda bid was to enhance the portfolio of generic drugs and OTC medicines, entering into emerging markets (i.e. China, Russia, or the Middle East) and therefore become a leading global firm that competes with Teva, Pfizer, and Perrigo. Mylan expects to generate savings around $350 \mathrm{mn}$ USD by leveraging operations between both companies. This allows to move from a pure generic prescription drug maker to a diversified health-care company available on a global level.

Mylan sales grew significantly higher from 2.6bn in Q2 2016 to 3.3bn in Q4 2016, toward 2.7bn USD in Q1 2017, representing a year-on-year growth of $24.1 \%$. The net profit was higher 
than the industry average hiking to $12.8 \%$ in Q4 2016 stabilizing at 2.4\% in Q1 2017. Mylan's operating CF is healthy at $425.6 \mathrm{mn}$ USD and net income of $66.4 \mathrm{mn}$ USD. The company shows a high return on equity (ROE) at $4.8 \%$ and a good FCF margin at $15.6 \%$.

The earnings multiple is appealing. Mylan showing a P/E ratio of 38.8, compared to the benchmark S\&P 500 at 21.4. The price/sales multiple shows the current stock price to the total assets, showing Mylan at 1.8 in favor to the S\&P 500 at 2.1. This shows that the stock is attractive, however currently overvalued. Under- and overvaluation of the stock depends on macro-factors and market conditions. EPS, showing the profitability of one single share, shows healthy data at 0.93 . Finally, the market capitalization, representing the price to buy a firm, is performing positively at $20.51 \mathrm{bn}$, suggesting that Mylan shares are safer than lower market capitalization firms. Pursuing a deal by acquiring a target boosts the acquirer revenue growth, translating into a growth of share price.

Overall, one can say that the acquisition of Meda was positive for Mylan to externally grow with global competitive market advantages. The firm shows solid operating margins, good net margins, healthy FCF margins, and high ROE. Negative aspect of the transaction was that Mylan bought also Meda's debt, leaving Mylan with a high debt burden at 16.4bn USD, showing a debt/equity ratio of 1.41.

However due to their abuse in price hike for the epinephrine auto injector EpiPen, they entered in Q2 2017 into a lawsuit for the violation of consumer protection laws. Therefore, the share price has dropped in April 2017 significantly. This translates, if an investor bought 100 shares of Mylan on the announcement day to buy Meda (16 February 2016) at the share price of 43.15 USD per share, Year-to-date (YTD) his value (24 July 2017 ) would have dropped by $10.03 \%$ to 38.82 USD per share.

\subsection{Tax inversion}

Tax inversion formed also a major motive for M\&A deals during recent years as the corporate tax in the United States is at $35 \%$, the highest of all developed countries. One needs to mention that the practice of tax inversion started already back in the 1990s shifting primarily to Bermuda or Cayman islands through the creation of a new holding (subsidiary) owned and operated by the founding company that allows paying US taxes on income earned in the offshore country. Therefore, the US tax code Article 1248 taxing gains from certain sales or exchanges of stock in certain foreign corporations [31] with the goal to discourage tax inversions was created. Tax inversion is a lucrative tax strategy for all corporations by relocating a legal domicile to a lower tax nation (i.e. Ireland, Netherlands), often by retaining the material operation in the higher tax-country nation. In the pharmaceutical industry, this phenomenon was majorly seen by buying smaller competitors in a tax heaven and reincorporating in a foreign country. This allows that the profits generated abroad are taxed domestically with the difference between the United States and the rate of the foreign country. An example is Pfizer targeting Allergan based in Ireland, in November 2015. By shifting Pfizer's tax domicile to Ireland, they would pay for every dollar earned in profit 12.5 cents tax in Ireland $(12.5 \%$ corporate tax rate in Ireland) plus 22.5 cents in the United States, but the last one only when the profits would be brought back to the United States. This deal would have allowed Pfizer benefiting from lower corporate tax rates as they are generating a huge proportion of cash abroad. US companies are trying to generate profits overseas and invest them back in offshore operations to avoid the US taxes (i.e. 22.5 cents in Pfizer's case) [32].

As the 152bn USD mega merger would have created one of the biggest US tax inversions, the White House started considering laws halting inversions or even prohibiting them completely, as they could destroy the US tax base, i.e. making earning stripping less attractive, by decreasing companies' offshore profits shift abroad by applying intracompany loans; or at least $25 \%$ of the group's employees, assets, and income have to be located or at least derived in the tax heaven, in contrast to previously $10 \%$; or US firms must merge with bigger companies to avoid that US shareholders have more than $80 \%$ by vote and value. Otherwise, the offshore company would still be treated as US firm must be paying taxes in income received in the United States and repatriated income earned abroad. This shows that Obama was strictly against these deals, as less tax revenues mean for the country less money for infrastructure, schools, transportation, and creating a bigger cliff between the social classes. Obama mentioned, 'When companies exploit loopholes like this it makes it harder to invest in the things that are going to keep America's economy going strong for future generations' [33]. Therefore, the attempt from Chicago-based company AbbVie trying to buy the Irish pharmaceutical company Shire for USD 52bn also collapsed as AbbVie's overseas cash that would have funded the deal would have taxed by the US corporate tax [34].

Recent analysis from the Institute of Taxation and Economic Policy (ITEP) showed that the Fortune 500 companies have avoided over USD 767bn in federal US income taxes [35]. This shows that tax inversions can still be strategically vice very lucrative for growing bigger, increasing competitive advantage and often answer shareholder expectations as they minimize the overall tax expenses, and therefore dividends might become higher. However, the social and ethical factors can be controversial as tax avoidance in the United States harm the government and therefore overall society [36]. This said in case that companies increase the dividends, the logical consequence of tax growth is behind, as shareholders have to pay taxes on their dividends.

According to the ITEP, the Fortune 500 companies are holding USD 2.6trn non-repatriated money abroad, where they often had to pay less than $10 \%$ income tax [37]. Repatriation of the money would foster the US economy (i.e. acquisition of new machines, research places, new employment, etc.), but it will only take place in case of more advantageous US rates, as they are subject to US tax rates of $35 \%$ minus the tax credit (tax paid to the foreign government).

This shows that tax inversion can be a strategic decision, also used by pharmaceutical companies, such as Mylan acquiring Abbott's specialty and generic business in non-US developed markets for 5.3bn USD to shift the tax domicile to the Netherlands, allowing them to decrease their taxed to the 
high tenner [36]. One can argue that this practice is also resilient to the core business strategy as pharmaceutical players want to save costs and grow organically as much as they can.

This said, the importance lies with the Trump's Q3/Q4 reforms to harmonize the US corporate tax rate with other competitive countries, lowering them closer to 20\% [38]. On 2 December 2017, the Senate passed the tax plan lowering the corporate tax rate from $35 \%$ to $20 \%$ and future foreign profits of US-based firms would be mostly exempt from tax [39]. This said, pharmaceutical companies would benefit from this reduced tax rate, also on repatriated earnings, and therefore would reduce focusing tax heavens outside the United States.

\section{Are M\&A deals in the pharmaceutical industry harming medical innovation?}

Lastly, this paper focuses briefly whether M\&A deals in the pharmaceutical industry harm medical innovation. The biggest concerns of M\&A deals for scientists and patients are that first they concentrate the market, leading to fewer innovations and second increasing the market share of few leading companies mainly in terms of marketing, sales, and distributions and therefore decrease competition.

(1) $M \& A$ is changing the market landscape; however, it does not decrease innovations. Figure 5 shows that even in the megamerger years 2014/15, filings were at their record highs with 40, respectively, 41 filings, and 40 approvals in 2014 (11 biologics license approvals and 30 new drug approvals) and 45 approvals in 2015 (12 biologics license approvals and 33 new drug approvals). The year 2016 shows some signs of fatigue, with only in total 19 new molecular entities FDA approvals, but 36 filling received. This shows that $M \& A$ activity is not a factor of fewer innovations, and the industry is bringing new drugs to the market.
One can argue that the big companies are dependent on acquiring smaller, niche-specialized firms (i.e. biopharmaceutical companies, tech firms), to fuel their pipeline and remain competitive. The increase in $M \& A$ reflects this transformation.

(1) Second concern was that large companies increase their market share, mainly in terms of marketing, sales, and distributions and therefore decrease competition. New regulations, pricing pressures are increasing costs that small companies cannot cover. Therefore, small companies often opt to sell their niche innovation assets or entire companies to bigger companies, and big companies benefit as they can leverage their existing marketing and distribution channels. Another competitive advantage of larger companies is that they can cover the costs of filling with the FDA. This shows that in a decade where blockbusters are expiring, $M \& A$ is a significant driver trying to find new drugs, with small companies being the innovators, and large companies being the acquirer of innovations and adding value to the commercialization of new drugs [41]. This shows that $M \& A$ changes the industry but does not create any harm, as small companies are creating innovation, and large companies are taking over when it becomes too costly for the small players.

This means that $M \& A$ transactions are structurally changing the pharmaceutical industry, but it has been proven that innovations are not harmed through mergers. M\&A creates vibration and it will depend manly on external factors, such as regulatory requirements or pricing pressures.

\section{Conclusion}

One can say that the pharmaceutical industry is undergoing major shifts in modern history. The industry has already experienced major changes, and it is still in a state of

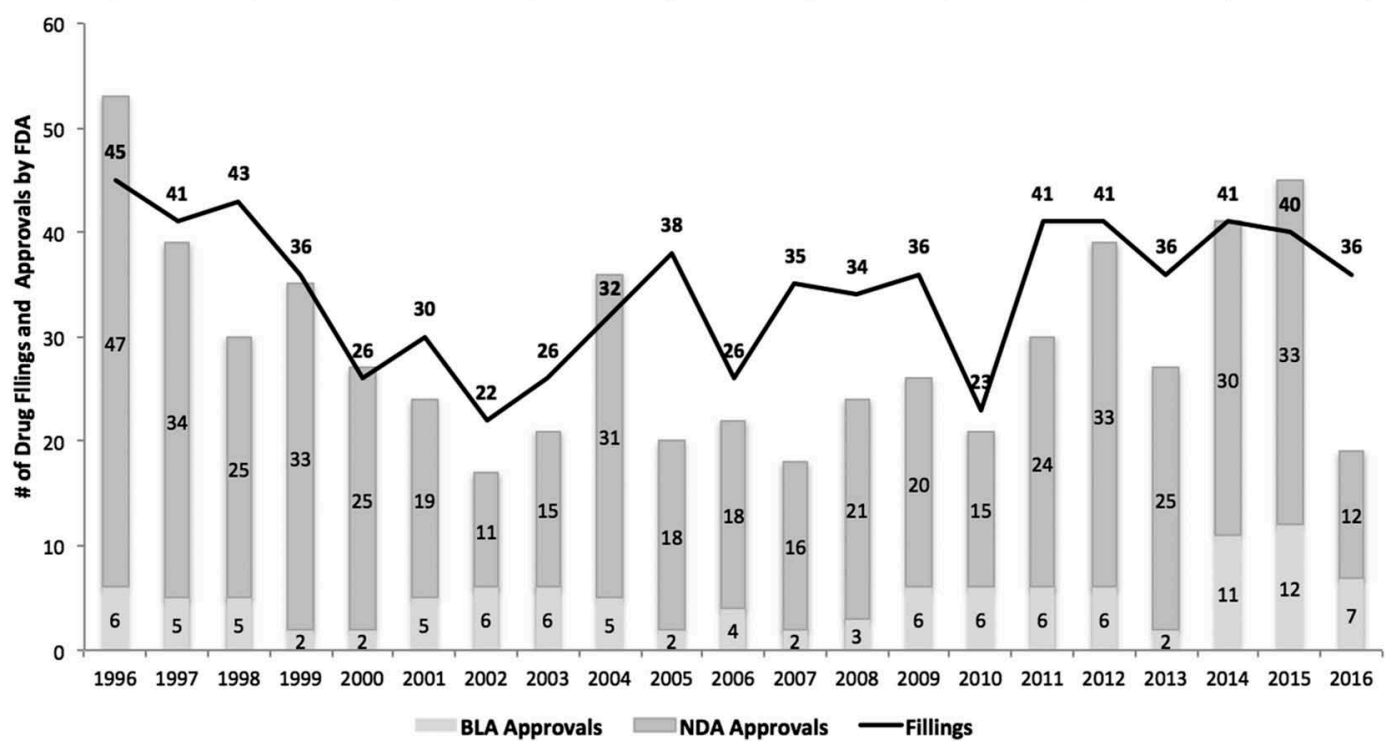

Figure 5. \# of Drug Fillings and Approvals by FDA, 1996-2016 [40]. 
continuous movements. On the one side of the coin, the industry and its stakeholders are consistently challenged, as patents are expiring, competition increasing, profits declining, and costs exploding. On top of that, political and economic movements are challenging the entire industry, such as the Brexit or elections with Trump's election in the United States and also a turbulent election area in Europe. As outlined above, the question is not if one can survive but rather how companies can thrive.

However, on the good side of the coin, knowledge and experience in health with high infrastructure, access to new innovative drugs and therapies, an increase in global wealth with less unemployment, more society knowledge through self-education, and labor are the three key areas increasing the pharmaceutical industry. Both sides of the coin are challenging the pharmaceutical industry, and therefore pharmaceutical companies need more than ever take control in advance by anticipating changes through knowing the entire macro- and micro-landscape.

The pharmaceutical industry will be dominated by pharmaceutical companies that are able to react to internal and external changes and enhance their competences by taking advantage of movements. This can be done as outlined in this paper either by in-house innovations, however that is very costly and time constraining, or by outsourcing through collaborations or M\&A deals. The core focus is finding new innovative molecules and therapies by focusing on specialist pipelines that enhance and save human lives. Therefore, the recommendation goes to the shark theory, meaning that big pharmaceutical companies should benefit from their luxury of the ability of making key decisions and acquire vital research and early clinical trial stages from smaller competitors focusing only on view niche molecules (i.e. biopharmaceutical or biotech companies), to develop costly late stage clinical trials, meeting all required regulations, and create the distributional access to patients for the new drugs. In the next years, one can expect that $M \& A$ deals are rebounding in terms of value as (1) large players are looking to get rapid and efficient drugs in their pipelines, meaning also an increase of filling with the FDA and (2) the financial future seems overall healthy as debt is cheap, companies have good CFs, and the big companies have still strong $P / E$ ratios.

\section{Expert commentary}

The pharmaceutical industry is undergoing major changes due to a changing macro- and micro-landscape. On top of external changes, patents are expiring which harms the revenues. To respond the fast-moving environment, and to create new innovative drugs, pharmaceutical companies are strategically looking to generate inorganic growth through M\&A, venture capitals or partnerships. Main motives behind consolidations such as $M \& A$ are selling off noncore assets, enhancing the existing portfolio inorganically and diversify, as well as tax inversion in regards to US companies. This said, one sees a consolidation and shift of the entire pharmaceutical industry. Scientists and patients fear that through an increase in M\&A activity, innovations will decline as the market gets less penetrated and motivation for innovation would shrink. However, looking at the last years of M\&A and new drug approvals from the FDA, one can argue optimistically that $M \& A$ changes the landscape with different market players responsible for different tasks and generates more intra-dependencies but does not decrease innovation.

\section{Five-year view}

One can be pretty optimistic that M\&A and further consolidations will shape the next years in the pharmaceutical sector. External and internal conditions factorize and increase $M \& A$ transactions such as volatile market conditions, increase in competition, increasing demand due to an aging population, growing demand from emerging markets and also increasing patent expirations. Thereunto, companies have cash as they are selling of their noncore assets and debt is cheap. Therefore, deal-making activities acquiring new drugs or technologies will continue to trend upward. The future drug pipeline will be guided by acquisitions and outsourcing as new drug developments are getting more and more complicated due to rising regulatory requirements, pricing pressures and are more time intestines.

\section{Key issues}

- Changing market due to expiration of blockbusters and drugs patents

- Difficulties discovering new key innovations creating scientific advantages due to higher macro constraints and different market conditions

- Creation of growth through inorganic rather than organic growth as it allows generating revenues

- Political uncertainties due to elections in the US and Europe as well as a general overvaluation of companies declined M\&A deal volume in 2016

- The market is waiting for Trump's key decisions regarding the US tax reform rate, whether the corporate rate will be declined from $35 \%$ and what conditions regarding repatriation of cash will be defined, as this will shape the M\&A future of US companies

- Currently one sees a Bull market without share prices having dropped 20\% in the S\&P 500 since March 2009 that favour M\&A activity

- Over the next years one can expect an increase in M\&A deals due to favourable market conditions and in order to reply the demand (i.e. Personalised drugs, advancement in 3D printer etc.

\section{Funding}

This paper was not funded.

\section{Declaration of interest}

The authors have no relevant affiliations or financial involvement with any organization or entity with a financial interest in or financial conflict with the subject matter or materials discussed in the manuscript. This includes employment, consultancies, honoraria, stock ownership or options, expert testimony, grants or patents received or pending, or royalties. 


\section{References}

Papers of special note have been highlighted as of considerable interest $(\cdot \cdot)$ to readers.

1. EFPIA. Pharmaceutical R\&D expenditure in Europe, USA and Japan (million of national currency units*), 1995-2015. 2016 Dec 31 [cited 2017 Dec 12]. Available from: https://www.efpia.eu/publications/ data-center/the-pharma-industry-in-figures-rd/pharmaceutical-rdexpenditure-in-europe-usa-and-japan/

2. Dierks $R$, Bruyère $O$, Reginster JY, et al. Macro-economic factors influencing the architectural business model shift in the pharmaceutical industry. Expert Rev Pharmacoecon Outcomes Res. 2016 Oct $05 ; \mathrm{sec}$. A;1:1-6.

.- It focuses on the macroeconomic factors that change the pharmaceutical industry.

3. Kurmann Partners. Cooling down - or the calm before the storm. 2017 Jan 31 [cited 2017 Aug 11]. Available from: http://www.kur mannpartners.com/fileadmin/user_upload/import2015/MRPharma_Biotech/KP_-_The_year_2016_in_review.pdf

4. Novartis. Kenya first country to launch 'Novartis Access', expanding affordable treatment options against chronic diseases. 2015 Oct 15 [cited 2017 Dec 12]. Available from: https://www.novartis.com/ news/media-releases/kenya-first-country-launch-novartis-accessexpanding-affordable-treatment

5. EvaluatePharma. World preview 2017, outlook to 2022. 2017 June 30 [cited 2017 Aug 20]. Available from: http://info.evaluategroup. com/rs/607-YGS-364/images/WP17.pdf

6. KPMG. 2017 M\&A predictor. 2017 Jan 31 [cited 2017 Aug 05]. Available from: https://assets.kpmg.com/content/dam/kpmg/xx/ pdf/2017/04/global-manda-deals.pdf

7. Moody's. Global pharma industry outlook change to stable reflect lower growth expectations. 2016 Mar 03 [cited 2017 Aug 05]. Available from: https://www.moodys.com/research/MoodysGlobal-pharma-industry-outlook-change-to-stable-reflects-lowerPR_345012

8. KPMG. 2017 M\&A predictor. 2017 July 31 [cited 2017 Aug 05]. Available from: https://assets.kpmg.com/content/dam/kpmg/xx/ pdf/2017/04/global-manda-deals.pdf

9. Investopedia. Valuation. 2017 Jan 31 [cited 2017 Aug 05]. Available from: http://www.investopedia.com/terms/v/valuation.asp

10. Bloomberg. Bloomberg professional. 2017 [cited 2017 Aug 25]. Available from: Subscription Service

- Main financial data can be retrieved to enable calculations and analyses.

11. Kurmann Partners. Global M\&A report pharma/biotech 2016. 2016 Jan 31 [cited 2017 Aug 11]. Available from: http://www.kurmann partners.com/fileadmin/user_upload/import2015/MR-Pharma_ Biotech/KP_-_The_year_2016_in_review.pdf

12. Christy G. Free cash flow: seeing through the accounting fog machine to find great stocks. 2009 Feb 09. sec. A. pp.50-76

13. California Biomedical Research Association. Factsheets: CBRA drug development 2016 July 31 [cited 2017 Aug 01]. Available from: https://www.ca-biomed.org/pdf/media-kit/fact-sheets/ CBRADrugDevelop.pdf

14. Bloomberg. Bloomberg professional. 2017 [cited 2017 Oct 03]. Available from: Subscription Service

15. Pfizer. Pfizer to acquire medivation. 2016 Aug 21 [cited 2017 Aug 18]. Available from: http://www.pfizer.com/news/press-release/ press-release-detail/pfizer_to_acquire_medivation https://www. medivation.com/

16. CNBC. Medivation shares leap on Pfizer's USD 14 billion offer. 2016 Aug 22 [cited 2017 Aug 18]. Available from: https://www.cnbc.com/ 2016/08/22/medivation-shares-surge-on-14-billion-dollar-offerfrom-pfizer.html

17. Pfizer. Pfizer completes acquisition of medivation. 2016 Sep 28 [cited 2017 Aug 18]. Available from: http://www.pfizer.com/news/ press-release/press-release-detail/pfizer_completes_acquisition_ of_medivation

18. Astellas. FDA accepts for review supplemental new drug application for $\mathrm{XTANDI}^{\circledR}$ (enzalutamide) capsules in metastatic castration-resistant prostate cancer with data from head-to-head studies of enzalutamide versus bicalutamide. 2016 Feb 28 [cited 2017 Aug 20]. Available from: http://newsroom.astellas.us/201602-22-FDA-Accepts-For-Review-Supplemental-New-DrugApplication-for-XTANDI-enzalutamide-Capsules-in-MetastaticCastration-resistant-Prostate-Cancer-with-Data-from-Head-to-HeadStudies-of-Enzalutamide-Versus-Bicalutamide

19. World Health Organization. Cancer key facts. 2017 Feb 28 [cited 2017 Aug 20]. Available from: http://www.who.int/mediacentre/ factsheets/fs297/en/

20. Crawford ED. Moving forward in castration-resistant prostate cancer: the TERRAIN and STRIVE studies. 2016 May 10 [cited 2017 Aug 20]. Available from: http://www.ascopost.com/issues/may-10-2016/ moving-forward-in-castrate-resistant-prostate-cancer-the-terrainand-strive-studies/

21. Grover N. Mylan to buy Swedish drugmaker Meda in $\$ 7.2$ billion deal. 2016 Feb 11 [cited 2017 Sep 02]. Available from: http://www. reuters.com/article/us-meda-m-a-mylan-nl-idUSKCNOVJ2IK

22. Nordenstam S, Shanley M Swedish drugmaker Meda spurns Mylan takeover approach. 2014 Apr 04 [cited 2017 Sep 02]. Available from: http://www.reuters.com/article/us-meda-mylanidUSBREA3310020140404

23. Wieczner J Fat pharma: Pfizer-Hospira and the top 10 overpriced drug deals ever. 2015 Feb 06 [cited 2017 Sep 02]. Available from: http://fortune.com/2015/02/06/pfizer-hospira-top-10-fattestpharma-deals/

24. Bloomberg. Bloomberg professional. 2017 [cited 2017 Sep 02]. Available from: Subscription Service

25. Staff R. AstraZeneca sells aging beta-blocker to Recordati for $\$ 300$ million. 2017 May 22 [cited 2017 Sep 02]. Available from: http:// www.reuters.com/article/us-astrazeneca-recordati-idUSKBN181000

26. Ogilvie J. Management accounting financial strategy. CIMA official learning systems. 2008 Jul 08;9:271-272.

27. Palmer E. Novartis follows brand offloading trend, selling drugs in Japan to Sun. 2016 May 30 [cited 2017 Sep 02]. Available from: http://www.fiercepharma.com/pharma/novartis-follows-brand-off loading-trend-selling-drugs-japan-to-sun

28. White C. Strategic management, Palgrave Macmillan. 2004 Feb 16. sec. A. $779-781$

29. Shipway I. Modern portfolio theory. Oxford Academic. 2009 Apr 01;15(2):66-70.

30. Jansen S. Mergers \& Acquistions - unternehmensakquisitionen und -kooperationen [Translated: Corporate Acquisitions and CoOperation. A Strategic, Organizational and Capital Market Theory Introduction]. Eine Strategische, Organisatorische Und Kapitalmarkttheoretische Einführung. 2016 Feb 02;6:30-70.

31. Jensen $M$. The agency cost of free cash flow, corporate finance and takeovers. American Economic Review. 1986 May 05;76(2):323-329.

32. Legal Information Institute. 26 U.S. Code $\S 1248$ - Gain from certain sales or exchanges of stock in certain foreign corporations.2017 Sep 15 [cited 2017 Sep 15]. Available from: https://www.law.cornell. edu/uscode/text/26/1248

33. Kollewe J, Treanor J. Pfizer formally abandons $\$ 160 \mathrm{bn}$ Allergan deal after US tax inversion clampdown. 2016 Apr 06 [cited 2017 Sep 18]. Available from: https://www.theguardian.com/business/2016/apr/05/ pfizer-allergan-merger-tax-avoidance-rules

34. Treasury. Fact sheet: treasury actions to rein in corporate tax inversions. 2014 Sep 22 [cited 2017 Sep 18]. Available from: https://www. treasury.gov/press-center/press-releases/Pages/jl2645.aspx

35. Gelles D, Bray C Drug firms make haste to elude tax. 2014 Jul 14 [cited 2017 Sep 18]. Available from: https://dealbook.nytimes.com/ 2014/07/14/shire-and-abbvie-in-talks-over-53-billion-pharmaceuti cal-merger/?mcubz=1

36. Institute of Taxation and Economic Policy. Fortune 500 companies hold a record \$2.6 trillion offshore. 2017 Mar 28 [cited 2017 Sep 20]. Available from: https://itep.org/wp-content/uploads/pre0327.pdf

37. Grahame RD. Curious case of corporate tax avoidance: is it socially irresponsible? 2014 Sep. 15. sec A., 173-184.

38. Cox J Wall Street week ahead: tax reform, tech and the latest on the housing market. 2017 Sep 25 [cited 2017 Sep 25]. Available 
from: https://www.cnbc.com/2017/09/24/wall-street-week-aheadtax-reform-tech-and-the-latest-on-the-housing-market.html

39. Bloomberg. What we know about corporate winners and losers in US Tax Bill. 2017 Dec 4. [cited 2017 Dec 6]. Available from: https:// www.bloomberg.com/news/articles/2017-12-04/what-we-knowabout-corporate-winners-and-losers-in-u-s-tax-bill
40. US. Food and Drug Administration. CDER 2016 actions and 2017 priorities. 2016 Dec 31 [cited 2017 Oct 19]. Available from: https:// www.fda.gov/downloads/AboutFDA/CentersOffices/ OfficeofMedicalProductsandTobacco/CDER/UCM533192.pdf

41. Capron L. Build, borrow or buy: solving the growth dilemma. 2012 Aug 12, 22-27 